\title{
Using microtomography and machine learning thermobarometry to reconcile the extreme explosivity of a mafic-alkaline volcano
}

\author{
CORIN JORGENSON ${ }^{1}$, LUCA CARICCHI ${ }^{1}$, MICHAEL \\ STUECKELBERGER $^{2}$, GIOVANNI FEVOLA ${ }^{2}$, GUIDO \\ GIORDANO $^{3}$, OLIVER HIGGINS ${ }^{1}$ AND GREGOR WEBER ${ }^{4}$ \\ ${ }^{1}$ University of Geneva \\ ${ }^{2}$ Deutsches Elektronen-Synchrotron \\ ${ }^{3}$ Roma Tre University \\ ${ }^{4}$ University of Oxford \\ Presenting Author: corin.jorgenson@unige.ch
}

Colli Albani is a large caldera complex in central Italy which has posed a puzzling problem: how can low viscosity maficalkaline magma produce ignimbrites of $50 \mathrm{~km}^{3}$ ? Contrary to the standard model of magma chemistry and explosivity relations, where high- $\mathrm{SiO}_{2}$ magmas are generally more explosive, Colli Albani offers a unique opportunity to reinvestigate the role of volatiles in mafic-alkaline systems through the lens of melt inclusions. Melt inclusions are a volcanologist's equivalent of a magmatic time capsule, where magma is captured within a crystallizing mineral and subject to only minor modifications on its journey to the surface. Thus, investigating the morphology and geochemistry of melt inclusions can provide us with valuable information about the processes modulating magma ascent and preceding volcanic eruptions.

Melt inclusions almost invariably contain bubbles, often rich in $\mathrm{CO}_{2}$ and $\mathrm{H}_{2} \mathrm{O}$, which must be taken into consideration when quantifying the volatile budget of magmas. The distribution of these vapour bubbles is integral to understanding the sequence of volatile exsolution. A large dataset of 79 high-resolution tomographic scans of clinopyroxene and leucite phenocrysts from Colli Albani was acquired at the Deutsches ElektronenSynchrotron (DESY). These tomograms allow us to accurately quantify the volume of melt inclusions and associated vapour bubbles for both glassy and microcrystalline melt inclusions. Notably, the glassy melt inclusions sometimes host multiple vapour bubbles at the rim of the melt inclusions - which we postulate indicates magma boiling.

To pin-point where fluid saturation occurs in the Colli Albani plumbing system, we perform thermo-barometry on clinopyroxene analyses collected near melt inclusions that were measured at the synchrotron using a recently developed machinelearning approach. Our results imply that magma was fluid saturated at the base of the crust or even in the mantle, suggesting that the magmas associated with the highly explosive eruptions of Colli Albani are already $\mathrm{CO}_{2}$-rich at depth. 